\title{
Resistencia de unión al cizallamiento de un adhesivo experimental con extracto de semillas de uva a esmalte humano post-blanqueado
}

\section{Shear bond strength of an experimental adhesive containing grape seed extract to human enamel immediately after bleaching}

\author{
Joanna Vola Gelmini ${ }^{a}$, Juana Rodríguez Barraguéb, Ignacio Migues Borghinic, Matías Mederos \\ Gómez ${ }^{d}$ Evandro Piva ${ }^{e}$
}

\begin{abstract}
:
The aim of is work is to evaluate the effect of the incorporation of grape seed extract and sodium ascorbate into a self-etching twostep experimental adhesive on the bond strength to immediate post-bleaching enamel. Eighty-four specimens were obtained from 42 third molars and randomly divided into 2 groups: one of these did not receive bleaching treatment $(\mathrm{N})$, while the other was bleached with $45 \%$ carbamide peroxide for 30 minutes (Y). Each group was subdivided into 3 groups depending on the adhesive system used: without antioxidant (C), adhesive with $15 \%$ sodium ascorbate (SA), and adhesive with $10 \%$ grape seed extract (GSE). A composite cylindrical was built up and then submitted to a shear bond strength test (SBS). A two-way ANOVA test was performed to evaluate the effect of the independent variables on the shear bond strength, using SigmaPlot 12.0 software. The significance level was $\alpha=0.05$. The groups with the highest bond strength results were N-C (34.67MPa \pm 8.79$)$, N-GSE (35.62MPa \pm 12.03$)$, and Y-C (29.48MPa \pm 6.94), without significant difference among them. The lowest SBS values were found in groups N-SA and Y-SA. None of the antioxidants improved the SBS values $(\mathrm{p}<0.05)$. The incorporation of GSE does not decrease the bond strength values. However, it is not capable of enhancing the bond strength after the bleaching process. In the case of sodium ascorbate, its incorporation into the primer of the experimental adhesive system seems to be ineffective.
\end{abstract}

Keywords:

Antioxidants, Ascorbic acid, Dental bonding, Grape seed extract, Shear strength, Tooth bleaching

Resumen:

El objetivo del presente trabajo fue evaluar el efecto de la incorporación de ascorbato de sodio y extracto de semillas de uva al primer de un sistema adhesivo experimental autoacondicionante de dos pasos, en la resistencia de unión inmediata a esmalte humano blanqueado. Se utilizaron 42 terceros molares de los que se obtuvieron 84 especímenes que se dividieron aleatoriamente en 2 grupos: la mitad de los especímenes no fue blanqueado, mientras que la otra mitad fue sometida a un procedimiento de blanqueamiento con peróxido de carbamida al $45 \%$ durante 30 minutos. Posteriormente, los especímenes fueron subdivididos en 3 grupos dependiendo del sistema adhesivo con el que fueron restaurados: adhesivo sin antioxidante, con ascorbato de sodio al $15 \%$, y con extracto de semillas de uva al 10\%. Se confeccionaron cilindros de resina compuesta que fueron sometidos a un ensayo de resistencia de unión al microcizallamiento. Se utilizó el programa SigmaPlot 12.0. Se realizó una prueba de ANOVA de dos vías para evaluar el efecto de las variables independientes en la RUM. Se utilizó un nivel de significancia de $\alpha=0.05$. Los grupos con mayores valores de resistencia de unión al microcizallamiento fueron: no blanqueado sin antioxidante $(34,67 \mathrm{MPa} \pm 8,79)$, no blanqueado con extracto de semillas de uva $(35,62 \mathrm{MPa} \pm 12,03)$ y blanqueado sin antioxidante $(29,48 \mathrm{MPa} \pm 6,94)$, sin diferencia estadísticamente significativa entre ellos. Los grupos en los que se utilizó el adhesivo con ascorbato, tanto el que recibió blanqueamiento como el que no fue blanqueado, mostraron los valores más bajos de resistencia de unión al microcizallamiento. Ninguno de los antioxidantes mejoró la resistencia de unión al microcizallamiento $(\mathrm{p}<0,05)$. La incorporación de extracto de semillas de uva al adhesivo no afecta negativamente la

\footnotetext{
a Universidad de la República, Uruguay; https://orcid.org/0000-0002-5003-4634, Email: j.vola@ @otmail.com

b Universidad de la República, Uruguay; https://orcid.org/0000-0003-4387-4675, Email: juanarodriguezb@hotmail.com

${ }^{c}$ Universidad de la República, Uruguay; https://orcid.org/0000-0003-4259-7290, Email: imigues@fq.edu.uy

${ }^{\mathrm{d}}$ Universidad de la República, Uruguay; https://orcid.org/0000-0002-1561-2283, Email: matiasmederos@ odon.edu.uy

e Autor de Correspondencia, Universidad Federal de Pelotas, Brasil; https://orcid.org/0000-0002-5970-5158, Email: evpiva@ gmail.com
} 
resistencia de unión al microcizallamiento. Sin embargo, no es capaz de mejorar la adhesión luego del blanqueamiento. En el caso del ascorbato de sodio, su incorporación en el primer del sistema adhesivo experimental parece no ser efectiva.

\section{Palabras Clave:}

Ácido ascórbico, Adhesión dental, Antioxidantes, Blanqueamiento dental, Extracto de semillas de uva

\section{Introduction}

The increasing demand for esthetic dentistry has resulted in a frequent practice of esthetic treatments. Among these, vital dental bleaching is a non-invasive option that can give a solution to tooth discoloration ${ }^{1,2}$. Several studies have demonstrated that the use of bleaching agents can lead to morphological alterations of the enamel surface, such as irregularities and reduced microhardness ${ }^{3-8}$ caused by loss of calcium, sulfates, phosphorus and, potassium, because of their $\mathrm{pH}^{9,10}$. Enamel organic compounds could be altered by free radicals, causing a reduced abrasion resistance $^{1,11}$ as well as postoperative sensitivity, pulp irritation, microleakage of existing restorations, and external root resorption ${ }^{7,12-16}$.

In most cases, this procedure needs to be combined with restorative treatments to achieve optimal esthetic results ${ }^{17}$. However, when adhesive procedures are performed immediately after bleaching treatments, the residual oxygen free radicals could interfere with the infiltration and polymerization of the adhesive ${ }^{8,18-20}$ causing a reduced bond strength ${ }^{4,21}$. As it has been demonstrated that this reduction is not permanent, a waiting period of one to three weeks after a bleaching procedure is recommended $^{18,22}$. After this waiting period, the replaced hydroxyl radicals re-enter the apatite matrix, resulting in the restoration of the structural changes caused by the incorporation of peroxide ions, which allows recovering the non-bleached bond strength values ${ }^{3,4,6-8,18,22}$. However, sometimes it is not possible to postpone the restorative procedure ${ }^{18,22}$.

To overcome this, different methods have been proposed, like the use of alcohol for treating bleached enamel, application of adhesives containing organic solvents, removal of the external enamel layer, and use of synthetic or natural antioxidant agents $3,5,8,9,13,22-25$. Sodium ascorbate, green tea extract, grape seed extract, and pomegranate peel extract are some antioxidants that can effectively improve bonding to bleached enamel ${ }^{26}$. The last ones, have the potential to neutralize free radicals and to interfere with their formation ${ }^{18,23}$. A systematic review about the use of antioxidants concluded that, independently of their type, form, concentration, and application time, it can be considered an adequate method to enhance the SBS to bleached teeth; and that its result can be as good as delaying the adhesive treatment for at least one week after bleaching ${ }^{14}$.
Sodium ascorbate is the most studied synthetic antioxidant and is considered the gold standard because it has been well evaluated in the literature $20,25,27$. However, it is a yellow and very unstable substance with a short shelf life, which oxidizes quickly, and can cause stains on newly bleached teeth. Scanning electron microscope images have shown that the application of sodium ascorbate results in excessive etching of the already bleached enamel surface ${ }^{28}$.

Because of the reasons mentioned above, noncytotoxic, low cost, with longer shelf life, natural alternatives have been researched ${ }^{29}$. Naturally occurring antioxidants are found in nature as a secondary metabolite of plants, widely present and available in fruits (nuts, grapes, cherries, blueberries, grapefruit peel extract, and cocoa), vegetables, seeds, flowers, and in certain tree species (pine bark, lemon tree bark, hazelnut tree leaves, and dried green tea leaves) ${ }^{1,3-5,18,30-32}$. Their clinical use is viable given their natural origin ${ }^{4,12,13,30,31}$. The different phenolic composition of these natural extracts determines their free radical scavenging ability ${ }^{3}$.

Oligomeric proanthocyanidin complexes found in grape seed extract have a great free radical scavenging capacity. Their antioxidant activity has been reported to be 20 times more potent than vitamin $\mathrm{E}$ and 50 times more potent than vitamin $\mathrm{C}$, from which sodium ascorbate is obtained $^{4,5,13,15,30,31}$.

The incorporation of sodium ascorbate (SA) and grape seed extract (GSE) as antioxidant agents in an adhesive could make it possible to perform an adhesive restoration immediately after a bleaching treatment. Moreover, it would be not necessary to add an extra step in order to apply the antioxidant, reducing the technique complexity, and shortening the chair time. This possibility implies a great advantage when the esthetic aspect is considered because it would not be necessary for the patient to maintain unchanged the existing adhesive restorations, which now differ from the post bleaching enamel color ${ }^{1,3,9,13,20,21,23,24,29,31,33}$.

Hence, the aim of this study was to evaluate the effect of the incorporation of SA and GSE to the primer of a self-etching (SE) two-step experimental adhesive in the immediate bond strength to bleached enamel. The hypothesis tested was that there would be no difference in immediate bond strength when using the experimental adhesives with and without the mentioned antioxidants. 


\section{Materials and methods}

The present study was approved by the Ethics Committee of the Faculty of Dentistry, Universidad de la República, Uruguay. File N091900-000189-18.

\section{Experimental design}

In this study, the shear bond strength of an experimental adhesive to human enamel was evaluated according to the following factors: 1) enamel bleaching treatment at two levels: with and without bleaching; 2) adhesive system at three levels: control, SA, and GSE.

\section{Adhesive formulation}

An experimental two-step adhesive system was formulated $^{34-36}$. The primer was modified by the addition of two different antioxidant agents (AA): 10\% Grape seed extract (Mega Natural Gold Grape Seed Extract, Polyphenolics, Madera, California, USA) and 15\% sodium ascorbate (Merck KGaA, Darmstadt, Germany). For that purpose, $0.5 \mathrm{~g}$ of GSE and $0.75 \mathrm{~g}$ of SA were incorporated into $5 \mathrm{~g}$ of adhesive respectively ${ }^{1,3,9,29,30,37}$. The $A A$ was weighed on an analytical balance (OHAUS Explorer® Semi Micro). Both mixtures were shacked on a magnetic stirring plate (SCIENCE MED model SM-H380-PRO) for 5 minutes. The mixture procedure was performed in a dark room to avoid premature polymerization. After complete dissolution of the antioxidant, the mixtures were placed in dark bottles which were placed into an ultrasonic bath (Soner 203 Ultrasonic cleaner, Rocker Scientific Co) for 15 minutes, in order to eliminate bubbles. A primer without the incorporation of antioxidants was used as a control.

\section{Table 1. Chemical composition of the adhesive used}

\begin{tabular}{ccc}
\hline Bottle & Components & Weight \% \\
\hline Primer & GDMA-P & 30 \\
& HEMA & 30 \\
& Water & 20 \\
& Ethanol & 20 \\
Adhesive & Bis-GMA & 50 \\
& TEGDMA & 25 \\
& HEMA & 25 \\
& Photo- & $0.4,0.8,0.8$ \\
& initiator (CQ, \\
& EDAB, \\
& DPHIHF)
\end{tabular}

GDMA-P: Glycerol dimethacrylate phosphate; HEMA: Hydroxyethyl methacrylate; Bis-GMA: Bisphenol A Glycidyl methacrylate;
TEGDMA: Triethylene glycol dimethacrylate; CQ: camphorquinone; EDAB: ethyl-4-dimethylamino benzoate; DPHIHF: diphenyl iodonium hexafluorophosphate.

The double bond conversion degree was tested to determine if the antioxidant modified adhesives reached optimal levels of polymerization ${ }^{38}$. In order to evaluate the degree of conversion and check that the incorporation of GSE and SA did not interfere with the degree of conversion, an infrared spectrophotometer equipped with an attenuated total reflectance (ATR) cell, was used Prestige 21 (Shimadzu, Tokio, Japón). A small sample of the previously mixed adhesive was placed in the cell and an infrared spectrum was sized. After that, the sample was irradiated for 30 seconds and a new infrared spectrum was sized. The procedure was repeated 3 times in each experimental group $(n=3)^{38}$.

\section{Specimen preparation and bleaching procedures}

The specimens were collected, cleaned, and stocked following the ISO/TS11405:2003 recommendations. Fortytwo sound third molars from patients aged 16 to 40 years, who gave their written consent for this purpose, were obtained. Tissue debris was removed by ultrasonic cavitation and the cleaned molars were kept in distilled water at a temperature of $4{ }^{\circ} \mathrm{C}$ in a refrigerator, for a maximum period of six months. The crowns were sectioned $1 \mathrm{~mm}$ under the enamel cement junction with a diamond disc and then separated into buccal and lingual halves. The halves were then fixed in cylindrical plastic molds with cold-curing acrylic resin (JET, Clássico LTDA; $\mathrm{SP}$, Brasil). The enamel surface was flattened under water irrigation with 600 grit carbide paper for 30 seconds using a metallographic double-disc polisher (J.P.S. Etudes Constructions; Paris, France). The 84 specimens obtained were sequentially numbered and then randomized into 6 different blocks ( $n=14$ ) according to the group in which they would be used by using a random number generator (Research Randomizer 4.0; Geoffrey C. Urbaniak and Scott Plous) (Table 2).

The sample size $(n=14)$ was estimated based on a previous study that evaluated the effect of the application of different antioxidant substances on shear bond strength to bleached enamel. Taking into account a comparative study design with 6 groups, a minimum detectable difference of 5.1 in the means, a standard deviation of 3.6, power of 0.8 and $\alpha=0.05^{26}$.

Bleaching and restorative procedures were performed by a single operator. For the groups that received bleaching treatment, $45 \%$ carbamide peroxide was used for 30 minutes following the manufacturer's indications (Opalescense Quick PF, Ultradent Products, Inc, UT, USA), simulating an in-office treatment ${ }^{39}$. The 
bleaching gel was applied over the enamel surface and then it was covered with adherent film, simulating an individual tray. After 30 minutes the gel was removed using distilled water. Immediately, a resin composite built up was made. For this, the enamel surface was etched using 35\% phosphoric acid for 10 seconds (Ultra Etch, Ultradent Products, Inc; South Jordan, UT, USA), washed with distilled water for 20 seconds, and dried with oil-free air for 10 seconds $^{40,41}$.

Table 2. Experimental groups

\begin{tabular}{ccc}
\hline GROUP & BLEACHING & ADHESIVE \\
\hline 1: N-C & NO & Control \\
2: N-SA & NO & Sodium ascorbate \\
3: N-GSE & NO & Grape seed extract \\
4: Y-C & YES & Control \\
5: Y-SA & YES & Sodium ascorbate \\
6: Y-GSE & YES & Grape seed extract \\
\hline
\end{tabular}

\section{Shear bond strength test}

The adhesive system was applied according to the Clearfil adhesive (Clearfil SE, Kuraray) manufacturer's instructions. The primer was rubbered over the enamel surface for 10 seconds and left for ten additional seconds before evaporating the residual solvent with air for 5 seconds. The hydrophobic adhesive was then applied with a brush, air blown gently, and polymerized for 10 seconds with a LED lamp (Radii-cal, SDI, Baywater, Victoria, Australia), with an irradiance of $900 \mathrm{~mW} / \mathrm{cm} 2$. The lamp was previously tested with a radiometer (Ophir, Optronics; North Logan, UT, USA).

A resin cylinder measuring $1.5 \mathrm{~mm}$ diameter and $1 \mathrm{~mm}$ height was built up (Brilliant NG, Universal DuoShade Nano-Hybrid Composite, Coltene Whaledent; RJ, Brasil) as follows: a single layer of composite was applied in a silicon matrix and covered with a glass microscope slide to avoid polymerization inhibition caused by oxygen contact. It was then photopolymerized for 20 seconds through the glass, applying the curing unit in contact with it (Figure 1). The specimens were then stored in distilled water for 24 hours at $37^{\circ} \mathrm{C}$ before the bond strength test. Shear bond strength (SBS) testing was performed in a universal testing machine (EMIC DL 500, Instron Equipamentos Científicos Ltda; São José dos Pinhais, PR, Brasil) at a cross-head speed of $0.5 \mathrm{~mm} / \mathrm{s}$, using a $100 \mathrm{~N}$ load cell. Bond strength values were calculated in MPa, considering the restoration area $(1.5 \mathrm{~mm} 2)$ using the load required to debond the specimen ${ }^{42}$.

\section{Statistical analysis}

The data obtained were previously submitted to ShapiroWilk and Levene tests. Statistical analysis was performed using SigmaPlot 12.0 ( $\mathrm{GmbH}$, Alemania). A two-way analysis of variance test (ANOVA) and Tukey test were used to analyze the effect of the bleaching and the adhesive type on the bond strength data. Significance level was established at $p<0.05$.

\section{Results}

Table 3 shows the results of the evaluated materials degree of conversion. As it can be observed, the incorporation of the different antioxidant agents did not significantly affect the degree of conversion ( $p>0.05$ in all cases).

Table 3. Degree of conversion of the adhesives used

\begin{tabular}{ccc}
\hline Group & Mean & SD \\
\hline Negative control & $67.31^{\mathrm{a}}$ & 0.09 \\
Grape seed extract & $64.66^{\mathrm{a}}$ & 3.2 \\
Sodium Ascorbate & $61.87^{\mathrm{a}}$ & 3.46 \\
\hline
\end{tabular}

There were no statistically significant differences $(p<$ 0.05).

Table 4 shows the SBS values for the experimental groups. According to the statistical analysis, the SBS was significantly influenced by the bleaching procedure $(p=0.014)$ and the adhesive used $(p<0.001)$; however, the interaction between the factors was not significant $(p=0.074)$.

Table 4. SBS results (MPa)

\begin{tabular}{cccc}
\hline Adhesive & NO & BLEACHING & $\mathrm{p}=0.014^{*}$ \\
& BLEACHING & & \\
\hline Control & A 34.67 & A 29.48 & \\
& $(8.79)^{\mathrm{a}}$ & $(6.94)^{\mathrm{a}}$ & \\
GSE & A 35.62 & B 23.19 & \\
& $(12.03)^{\mathrm{a}}$ & $(12.5)^{\mathrm{ab}}$ & \\
SA & A 16.17 & A 16.59 & \\
& $(7.74)^{\mathrm{b}}$ & $(12.69)^{\mathrm{b}}$ & \\
$\mathrm{p}<0.001^{* *}$ & & & $\mathrm{p}=0.074^{* * *}$ \\
\hline
\end{tabular}

Different capital letters (lines) and lower case letters (columns) indicate statistically significant difference $(p<$ 0.05 ). ${ }^{*}$ Bleaching $p$ value. ${ }^{* *}$ Adhesive $p$ value. ${ }^{\star \star *}$ Bleaching versus adhesives $p$ value. 
Among the non-bleached groups, when SA was incorporated to the adhesive significantly lower $p$ values were obtained $(p<0.001)$. No significant difference was found between $\mathrm{N}-\mathrm{C}$ and $\mathrm{N}-\mathrm{GSE}(\mathrm{p}=0.968)$. On the other side, among the bleached groups, $\mathrm{Y}$-SA showed significantly lower values compared to $Y-C(p=0.004)$.

Considering the bleaching factor, only the groups where adhesive containing GSE was used showed a significant difference $(p=0.002)$. For the groups where no antioxidant was used and those where SA was incorporated, there was no significant difference $(p=0.191$ y 0.153 respectively).

\section{Discussion}

In this study, the SBS was evaluated in different situations: using a SE two-step experimental adhesive with and without antioxidants (GSE and SA), on human enamel with and without previous bleaching. It was not an objective of this study to evaluate whether the bleaching gel was effective or not. That is why this parameter was not evaluated.

Beyond being the current trend, the use of a twostep self-etching adhesive was the adhesive approach selected in this study since it gave the possibility to extend the contact time between the antioxidant agent and the bleached enamel surface for 20 seconds before applying and polymerizing the adhesive. It is well known that the total etching approach gives better results when enamel bond strength is at issue. This is the reason why the enamel surface was etched with phosphoric acid before applying the adhesive ${ }^{40}$.

According to the results, the SBS was significantly influenced by both the adhesive and the bleaching treatment. The SBS values were significantly lower in the groups where SA was incorporated into the adhesive. The bleaching treatment only affected negatively the SBS when considering the groups where GSE was incorporated into the adhesive. Taking these into account, the null hypothesis tested in this study was partially rejected.

It is well known that free radicals responsible for dental bleaching cause the SBS to decrease significantly $14,21-24,29-31,33,43$. In contrast with previous studies $(9,18,44,45)$, in this study the bleaching treatment did not diminish significantly the SBS values when compared to the not bleached control group. A possible explanation is that the bleaching agent used [carbamide peroxide (CP) $45 \%$ ] may not be capable of generating a high free radical concentration, since a given concentration of CP consists of 3.5 parts of HP and 6.5 parts of urea. This may explain why this bleaching agent did not significantly change the SBS values ${ }^{46,47}$.
Furthermore, the application time was 30 minutes, and since CP releases the HP slowly, it may have not been enough time for the bleaching agent to produce a significant amount of free radicals that could lead to a decrease in the SBS values ${ }^{48}$. On the other hand, it is widely known that the more concentrated a bleaching agent the more acidic it is. This acidity causes an important loss of minerals that leads to an alteration of the tooth structure surface such that it reflects light differently changing the perception of tooth color as well as decreasing its adhesiveness ${ }^{10,19,49}$. This is the reason why low concentrations of bleaching agents are preferred. However, the reason why $45 \% \mathrm{CP}$ was selected in this study was to give rise to an optimal concentration of free radicals. Moreover, $\mathrm{CP}$ decomposes in hydrogen peroxide (HP) and urea. The latter turns the AA more alkaline, decreasing the acidic effects on the substrate ${ }^{50}$.

Since combining dental bleaching and adhesive restorations to achieve esthetic results has become a frequent practice ${ }^{18}$, the use of antioxidant agents that make it possible to perform the restorative procedure immediately after the bleaching treatment has been proposed $^{8,22}$. Antioxidant agents are capable of scavenging the oxygen free radicals released by peroxides, increasing the enamel redox potential, allowing the polymerization of the resin composite's free radicals $^{8,16,29}$. These antioxidants can be synthetic, such as $\mathrm{SA}^{20}$, or natural, such as $\mathrm{GSE}^{16,18}$. Meanwhile $\mathrm{SA}$ is unstable $^{16}$, has a short shelf life, and can be mutagenic for mammalian somatic cells; GSE has no such disadvantages ${ }^{1,31,51,52}$. Moreover, GSE has a scavenging ability that is reportedly 50 times more potent than $S A^{5,15}$. Until now antioxidant agents have been incorporated, in solution form, as a separate previous step to the adhesive restorative procedure performed after a bleaching treatment. This means that the antioxidant must be applied for a certain time, often 10 minutes $^{27}$, washed, and then the adhesive procedure is continued as usual $1^{1,3,4,9,13,23,25,29,30,37,53-55}$. As an additional clinical step is needed, mistakes become more likely to occur and the chairside time is increased ${ }^{56}$. That is why, in this study the antioxidant was incorporated into the primer of a two-step self-etch adhesive system.

The double bond conversion degree was evaluated in order to determine the viability of the experimental adhesive. As it can be observed this parameter reached values of $60 \%$, comparable to Clearfil SE, Kuraray $63 \%{ }^{38,57}$. Once the AA (SA or GSE) was incorporated into the experimental adhesive, this parameter was assessed again to determine whether the composition modification resulted in an alteration in the degree of conversion. No significant difference was observed, so it was determined that the AA incorporation did not alter the adhesive degree of conversion. 
According to the results, the incorporation of GSE to the experimental adhesive did not diminish the SBS values. This could be observed when comparing the nonbleached groups where the adhesive used included GSE and where the adhesive did not incorporate any antioxidant. As there was no significant difference between these groups (N-C 34.675 \pm 8.79 ; N-GSE 35.628 \pm 12.03 ; $p$ $>0.05$ ), it could be inferred that this antioxidant agent did not interfere with the adhesive procedure.

Grape seed extract was chosen for this study among a variety of natural antioxidants because previous studies had shown its ability to improve ${ }^{1,3,7,9,15,51,52}$ and even restore the SBS to bleached enamel 4,5,13,18,19,29,58. However, in this study, GSE was not capable of improving the SBS values after the bleaching treatment, as it can be observed when comparing the groups N-GSE $(35.628 \pm 12.03)$ and Y-GSE (23.199 \pm 12.503$)$. These results are in accordance with a previous study by Sharafeddin et al. ${ }^{23}$. This could have been due to the fact that GSE was added to the primer of the experimental adhesive system, limiting the contact time to 20 seconds (in contrast to 10 minutes time reported in previous studies) and enabling chemical interactions with the primer components. According to Dhingra et al. ${ }^{51}$, the antioxidant agent must be applied for at least a third of the bleaching time in order to be effective. That is why most studies apply the antioxidant agents as a previous step, for at least 10 minutes.

GSE has been used in concentrations that vary from $5 \% \%^{3-5,7,13,19,29,30,58}, 6.5 \%{ }^{9,18,51}$ to $10 \%^{1,15,23,52}$. In this study, $10 \%$ GSE was used in an attempt to compensate for its limited application time, as this was the highest concentration tested that proved to be effective. These results should be considered with caution since the bleaching strategy used did not diminish significantly the SBS values, which may lead to a false negative.

In this study, SA was used as a reference parameter because it is one of the most used $A A^{20}$. In previous and current studies where this agent was used as a separate step before the adhesive procedure, SBS values were improved ${ }^{27,55,59-61}$ and even restored to the non-bleached control level ${ }^{27,55}$. A current study where 10\% SA is used for 10 minutes as a previous step concludes that this AA significantly increases the bond strength. Only when it was applied following bleaching with $5 \%$ and $10 \%$ $\mathrm{CP}$ there was no significant difference in the $\mu$ TBS values compared to the control group ${ }^{61}$.

Unlike the latter, in this study sodium ascorbate was incorporated into the primer of the experimental adhesive system. According to the obtained results, this strategy seems to be ineffective. On one hand, because it seems to alter the adhesive. This effect is evidenced in the SBS values when the groups that were not bleached were compared: when the primer without antioxidant was used, the SBS values were significantly higher $(34.675 \pm 8.79)$ than when SA was incorporated to the primer (16.175 \pm 7.744$)$.

On the other hand, when the primer with SA was used there were no improvements in the SBS values $(16.599 \pm 12.696)$. This is in accordance with previous studies $^{59,62,63}$ and can be partly explained by the contact time between the bleached enamel and SA. Previous studies have reported that ten minutes of application time is effective to enhance ${ }^{27}$ and even restore ${ }^{15}$ the diminished SBS values. Moreover increasing the application time up to 120 minutes has shown to improve the SBS ${ }^{53}$. Previous studies have shown that concentrations under $10 \%$ were not effective to restore the SBS, and concentrations over $20 \%$ do not lead to better results ${ }^{60}$. That is why in this study $15 \%$ SA was used.

Most resin-based dental materials used in esthetic dentistry cure via radical chain polymerization. An initiation system is needed to generate a free radical that "initiates" the polymerization process. Irrespective of their cure type (benzoyl peroxide / amine or other initiation systems), dental resin-based materials generally contain some inhibitors to extend their shelf-life. Inhibitors are added to suppress the polymerization of monomers and prevent premature polymerization ${ }^{64}$, which occurs especially in extreme storage conditions, such as high temperatures (for example during transport and shipping). Inhibitors are actually anti-oxidants that are able to scavenge free radicals originated from prematurely reacted initiators and prevent spontaneous initiation and propagation of the free-radical polymerization reaction. The most frequently used inhibitors in adhesives are butylhydroxytoluene (BHT) and monomethyl ether hydroquinone (MEHQ). Thus, inhibitors act as a freeradicals scavengers, and completely stop polymerization until the inhibitors are consumed, after which polymerization proceeds at the same rate as if the inhibitor was absent ${ }^{65}$. The chemical structure of SA is similar to the chemical structure of BHT and MEHQ. They all share the presence of hydroxyl groups in their composition, which can act as a radicals scavengers. Another possible explanation for the low values of SBS observed in this study when SA was used, could be that this AA is acting as an inhibitor, quenching free radicals and preventing the adequate polymerization of the adhesive system in situ.

Future studies should be conducted in order to experiment with other bleaching agents as well as other antioxidant agents. Furthermore, analyzing the failure mode could throw light on the alterations that the primer may suffer when it is modified by the addition of an antioxidant. If an adhesive system containing an antioxidant achieved good results in terms of SBS, it would be necessary to investigate about its shelf life and storage conditions. The effect of time on the bond durability was 
not evaluated in this study since no aging test was performed. The longevity of bonded restorations is to a large extent related to the degradation of the adhesive interface, which may occur in a relatively short term. Although bond strength values observed may be low, they can be stable in time. As this aspect was not assessed, it constitutes a limitation of this study ${ }^{66}$.

\section{Conclusion}

According to this study, the application of $45 \%$ carbamide peroxide during 30 minutes did not decrease the SBS when the adhesive procedure is performed immediately after the bleaching treatment. The addition of GSE to the primer of an experimental adhesive does not modify the SBS values reached with this adhesive. In contrast, the incorporation of SA impaired the adhesive's performance. Within the limitations of this study, the incorporation of GSE to the adhesive system did not improve the SBS values after the bleaching procedure.

\section{Referencias}

1. Subramonian R, Mathai V, Angelo J, Ravi J. Effect of three different antioxidants on the shear bond strength of composite resin to bleached enamel: An in vitro study. J Conserv Dent. 2015;18(2):144-8.

2. Güleç Alagöz L, Karadağlıoğlu İ, Ulusoy N. Antioxidants used in restorative dentistry. Cyprus J Med Sci. 2019;4(2):141-5.

3. Mukka PK, Komineni NK, Pola S, Soujanya E, Karne AR, Nenavath $\mathrm{B}$, et al. An in-vitro comparative study of shear bond strength of composite resin to bleached enamel using three herbal antioxidants. $\mathrm{J}$ Clin Diagnostic Res. 2016;10(10):89-92.

4. Abraham S, Ghonmode WN, Saujanya KP, Jaju N, Tambe VH, Yawalikar PP. Effect of grape seed extracts on bond strength of bleached enamel using fifth and seventh generation bonding agents. J Int Oral Heal. 2013;5(6):101-7.

5. Manoharan M, Shashibhushan KK, Poornima P, Naik S, Patil D, Shruthi AS, et al. Effect of newer antioxidants on the bond strength of composite on bleached enamel. J Indian Soc Pedod Prev Dent. 2016;34(4):391-6.

6. Grazioli G, Valente LL, Isolan CP, Pinheiro HA, Duarte CG, Münchow EA. Bleaching and enamel surface interactions resulting from the use of highly-concentrated bleaching gels. Arch Oral Biol. 2018;87:15762.

7. Bansal M, Kaur P, Cyriac AR, Kadian N, Jaiswal P, Rathee K. Impact of different antioxidants on the bond strength of resin-based composite on bleached enamel-an in vitro study. J Contemp Dent Pract. 2019;20(1):64-70.

8. Nari-Ratih D, Widyastuti A. Effect of antioxidants on the shear bond strength of composite resin to enamel following extra-coronal bleaching. J Clin Exp Dent. 2019;11(2):126-32.

9. Arumugam MT, Nesamani R, Kittappa K, Sanjeev K, Sekar M. Effect of various antioxidants on the shear bond strength of composite resin to bleached enamel: An in vitro study. J Conserv Dent. 2014;17(1):226.
10. Patil J, Reddy A, Shome Venigalla B, Shekar K, Ravichandra C, Binoy D. Effect of different concentrations of carbamide peroxide and green tea extract on the color and shear bond strength of enamel-an in vitro study. Endodontology. 2015;27(2):129-35.

11. Alqahtani MQ. Tooth-bleaching procedures and their controversial effects: A literature review. Saudi Dent J. 2014;26(2):33-46.

12. Sharafeddin F, Mehran M, Shiva M. Effect of immediate application of pomergranate peel, grape seed and green tea extracts on shear bond strength of in-office bleached enamel. Res J Biol Sci. 2013;8(3):83-7.

13. Vidhya S, Srinivasulu S, Sujatha M, Mahalaxmi S, Sujatha M, Mahalaxmi S. Effect of grape seed extract on the bond strength of bleached enamel. Oper Dent. 2011;36(4):433-8.

14. Feiz A, Mosleh H, Nazeri R. Evaluating the effect of antioxidant agents on shear bond strength of tooth-colored restorative materials after bleaching: A systematic review. J Mech Behav Biomed Mater. 2017 Jul;71(March):156-64.

15. Gogia H, Taneja S, Kumar M, Soi S. Effect of different antioxidants on reversing compromised resin bond strength after enamel bleaching: An in vitro study. J Conserv Dent. 2018;21(1):100-4.

16. Lopes MB, Felizardo KR, Brigantini LC, Berger SB, Laxe LAC, Salvio LA. Influence of antioxidants on bond strength of bleached dental substrates. 1 Lopes MB, Felizardo KR, Brigantini LC, Berger SB, Laxe LAC, Salvio LA Influ antioxidants Bond strength Bleach Dent substrates HU Rev 2018;44(1)63-76 HU Rev. 2018;44(1):63-76.

17. Khamverdi Z, Rezaei-Soufi L, Kasraei S, Ronasi N, Rostami S. Effect of epigallocatechin gallate on shear bond strength of composite resin to bleached enamel: an in vitro study. Restor Dent Endod. 2013 Nov;38(4):241-7.

18. Nair R, Bandhe S, Ganorkar OK, Saha S, Sial S, Nair A. A comparative evaluation of the three different antioxidant treatments on the bond strength of composite resin to bleached enamel: An in vitro study. J Conserv Dent. 2019;22(1):82-6.

19. Nair M, Nesamani R, Sanjeev K, Sekar M, Renganathan S. Effect of single and two step application of antioxidant incorporated bleaching agents on bond strength of resin composite and surface changes in enamel. Biol Med. 2016;8(7):1-5.

20. De Carvalho HC, Guiraldo RD, Poli-Frederico RC, Maciel SM, Moura SK, Lopes MB, et al. Correlation between antioxidant activity and bonding strength on bleached enamel. Acta Biomater Odontol Scand. 2016;2(1):102-7.

21. Ozelin AA, Guiraldo RD, De Carvalho RV, Lopes MB, Berger SB. Effects of green tea application time on bond strength after enamel bleaching. Braz Dent J. 2014;25(5):399-403.

22. Rana R, Kaushik M, Sharma R, Reddy P, Mehra N. Comparative evaluation of effects of natural antioxidants on the shear bond strength of composite resin to bleached enamel. Indian J Dent Res. 2019;30(1):112-6

23. Sharafeddin F, Farshad F. The effect of aloe vera, pomegranate peel, grape seed extract, green tea, and sodium ascorbate as antioxidants on the shear bond strength of composite resin to home-bleached enamel. J Dent Shiraz Univ Med Sci.. 2015;16(4):296-301.

24. Da Silva JMG, Botta AC, Barcellos DC, Pagani C, Torres CRG. Effect of antioxidant agents on bond strength of composite to bleached enamel with 38\% hydrogen peroxide. Mater Res. 2011;14(2):235-8. 
25. Lai S, Tay F, Cheung G, Mak Y, Carvalho R, Wei S, et al. Reversal of compromised bonding in bleached enamel. $\mathrm{J}$ Dent Res. 2002;81(7):477-81.

26. Elawsya ME, El-shehawy TM, Zaghloul NM. Influence of various antioxidants on micro-shear bond strength of resin composite to bleached enamel. J Esthet Restor Dent. 2020;(April):1-9.

27. Türkün M, Kaya AD. Effect of $10 \%$ sodium ascorbate on the shear bond strength of composite resin to bleached bovine enamel. J Oral Rehabil. 2004;31(12):1184-91.

28. Muraguchi K, Shigenobu S, Suzuki S, Tanaka T. Improvement of bonding to bleached bovine tooth surfaces by ascorbic acid treatment. Dent Mater J. 2007;26(6):875-81.

29. Khamverdi Z, Khadem P, Soltanian A, Azizi M. In-vitro evaluation of the effect of herbal antioxidants on shear bond strength of composite resin to bleached enamel. J Dent (Tehran). 2016 Aug;13(4):244-51.

30. Aulakh GS, Sharma P, Juneja A, Kumar P. Effect of grape seed extract and sodium ascorbate solution on the shear bond strength of ceramic brackets bonded to bleached enamel. J Dent Spec. 2016;4(2):108-12.

31. Aksakalli S, Ileri Z, Karacam N. Effect of pine bark extract on bond strength of brackets bonded to bleached human tooth enamel. Acta Odontol Scand. 2013;71:1555-9.

32. Castellan CS, Bedran-Russo AK, Karol S, Pereira PNR. Long-term stability of dentin matrix following treatment with various natural collagen cross-linkers. J Mech Behav Biomed Mater. 2011;4(7):134350 .

33. Sharafeddin F, Farshad F, Azarian B, Afshari A. Effect of green tea extract as antioxidant on shear bond strength of resin composite to in office and home-bleached enamel. J Dent Biomater. 2016 Sep;3(3):269-75.

34. Moreira AG, Cuevas-Suárez CE, da Rosa WL de O, Ogliari AO, Petzhold CL, Piva E, et al. Piperonyl methacrylate: copolymerizable coinitiator for adhesive compositions. J Dent. 2018;79:31-8.

35. Leal FB, Lima GS, Collares FM, Samuel SM, Petzhold CL, Piva E, et al. Iodonium salt improves the dentin bonding performance in an experimental dental adhesive resin. Int J Adhes Adhes. 2012;38:1-4.

36. Fontes ST, Ogliari FA, Lima GS, Bueno M, Schneider LFJ, Piva E Tetrahydrofuran as alternative solvent in dental adhesive systems. Dent Mater. 2009;25(12):1503-8.

37. Ismail EH, Kilinc E, Hardigan PC, Rothrock JK, Thompson JY, Garcia-Godoy C. Effect of two-minute application of $35 \%$ sodium ascorbate on composite bond strength following bleaching. J Contemp Dent Pract. 2017;18(10):874-80.

38. Herrera-González AM, Caldera-Villalobos M, Pérez-Mondragón AA Cuevas-Suárez CE, González-López JA. Analysis of double bond conversion of photopolymerizable monomers by FTIR-ATR spectroscopy. J Chem Educ. 2019;96(8):1786-9.

39. Dastjerdi EV, Khaloo N, Mojahedi SM, Azarsina M. Shear bond strength of orthodontic brackets to tooth enamel after treatment with different tooth bleaching methods. Iran Red Crescent Med J. 2015;17(11):0-3.

40. Cuevas-Suárez CE, da Rosa WL de O, Lund RG, da Silva AF, Piva E Bonding performance of universal adhesives: An updated systematic review and meta-analysis. J Adhes Dent. 2019;21(1):7-26.
41. Takamizawa T, Barkmeier WW, Tsujimoto A, Endo H, Tsuchiya K, Erickson RL, et al. Influence of pre-etching times on fatigue strength of self-etch adhesives to enamel. J Adhes Dent. 2016;18(6):501-11.

42. Meereis CTW, Suárez CEC, de Almeida SM, de Almeida CM, Piva E, Collares FM, et al. Dentin bonding performance of experimental onestep adhesives after incorporation of $\mathrm{POOH}-\mathrm{SiO} 2$ nanoparticles. Appl Adhes Sci. 2016;4(1):4-11.

43. Dishman M V., Covey DA, Baughan LW. The effects of peroxide bleaching on composite to enamel bond strength. Dent Mater1994;10(1):33-6.

44. Kadiyala A, Saladi HK, Bollu IP, Burla D, Ballullaya SV, Devalla S, et al. Effect of different antioxidants on shear bond strength of composite resins to bleached human enamel. J Clin Diagnostic Res. 2015;9(11):40-3.

45. Kavitha M, Selvaraj S, Khetarpal A, Raj A, Pasupathy S, Shekar S. Comparative evaluation of superoxide dismutase, alpha-tocopherol, and $10 \%$ sodium ascorbate on reversal of shear bond strength of bleached enamel: An in vitro study. Eur J Dent. 2016;10(1):109-15.

46. Li Y, Greenwall L. Safety issues of tooth whitening using peroxidebased materials. Br Dent J. 2013;215(1):29-34

47. Rodríguez-Martínez J, Valiente M, Sánchez-Martín MJ. Tooth whitening: From the established treatments to novel approaches to prevent side effects. J Esthet Restor Dent. 2019;31(5):431-40.

48. Tredwin CJ, Naik S, Lewis NJ, Scully Cbe C. Hydrogen peroxide tooth-whitening (bleaching) products: Review of adverse effects and safety issues. Br Dent J. 2006;200(7):371-6.

49. Kwon SR, Wertz PW. Review of the mechanism of tooth whitening. J Esthet Restor Dent. 2015;27(5):240-57.

50. Joiner A. The bleaching of teeth: A review of the literature. J Dent. 2006;34(7):412-9.

51. Dhingra A, Gupta AK, Minocha A, Sen N. Comparative evaluation of immediate bond strength to bleached enamel following application of various antioxidant solutions. Dent J Adv Stud. 2017;5(2):84-9.

52. Mohan M, Sudha K, Malini DL, Bindhu MS. Effect of three different antioxidants on shear bond strength of composites to bleached enamelAn in vitro study. Indian J Dent Adv. 2017;9(1):3-7.

53. Dabas D, Uppin V, Patil A. Evaluation of the effect of concentration and duration of application of sodium ascorbate hydrogel on the bond strength of composite resin to bleached enamel. J Conserv Dent. 2011;14(4):356

54. Lima Fonseca A, Fonseca da Silva M, Freitas Santiago M, Palialol Muniz AR, Aguiar Baggio FH, Marchi GM. Effect of bleaching treatment and reduced application time of an antioxidant on bond strength to bleached enamel and subjacent dentin. J Adhes Dent. 2011;13(13):537-42.

55. Türkün M, Celik EU, Kaya AD, Arici M. Can the hydrogel form of sodium ascorbate be used to reverse compromised bond strength after bleaching? J Adhes Dent. 2009;11(1):35-40.

56. Epasinghe DJ, Yiu CKY, Burrow MF, Tay FR, King NM. Effect of proanthocyanidin incorporation into dental adhesive resin on resindentine bond strength. J Dent. 2012;40(3):173-80. 
57. Cuevas-Suárez CE, Ramos TS, Rodrigues SB, Collares FM, Zanchi $\mathrm{CH}$, Lund $\mathrm{RG}$, et al. Impact of shelf-life simulation on bonding performance of universal adhesive systems. Dent Mater [Internet]. 2019;35(9):e204-19. Available from: https://doi.org/10.1016/j.dental.2019.05.023

58. Lokhande P, Manne D, Shivanna V, Nishad SV. Evaluation of 5\% proanthocyanidin and $30 \%$ alpha-tocopherol on shear bond strength of composite to bleached enamel: An In vitro study. J Dent Res Rev. 2019;5(4):128-31.

59. Sasaki RT, Flório FM, Basting RT. Effect of $10 \%$ sodium ascorbate and $10 \% \alpha$-tocopherol in different formulations on the shear Bond strength of enamel and dentin submitted to a home-use bleaching treatment. Oper Dent. 2009;34(6):746-52.

60. Kimyai S, Valizadeh $\mathrm{H}$. The effect of hydrogel and solution of sodium ascorbate on bond strength in bleached enamel. Oper Dent. 2006;31(4):496-9.

61. Ghaleb M, Orsini G, Putignano A, Dabbagh S, Haber G, Hardan L. The effect of different bleaching protocols, used with and without sodium ascorbate, on bond strength between composite and enamel. Materials (Basel). 2020;13(12):1-10

62. Torres C, Koga A, Borges A. The effects of anti-oxidant agents as neutralizers of bleaching agents on enamel bond strength. Brazilian J Oral Sci. 2006;5(16):971-6.

63. Kimyai S, Oskoee S, Rafighi A, Valizadeh H, Ajami A, Zadeh Z Comparison of the effect of hydrogel and solution forms of sodium ascorbate on orthodontic bracket-enamel shear bond strength immediately after bleaching: An in vitro study. Indian J Dent Res. 2010;21(1):54-8.

64. Kwon TY, Bagheri R, Kim YK, Kim KH, Burrow MF. Cure mechanisms in materials for use in esthetic dentistry. J Investig Clin Dent. 2012;3(1):3-16.

65. Van Landuyt KL, Snauwaert J, De Munck J, Peumans M, Yoshida Y, Poitevin A, et al. Systematic review of the chemical composition of contemporary dental adhesives. Biomaterials. 2007;28(26):3757-85.

66. Van Meerbeek B, Peumans M, Poitevin A, Mine A, Van Ende A, Neves A, et al. Relationship between bond-strength tests and clinical outcomes. Dent Mater. 2010;26(2):100-21. 